\title{
Changes in carabid beetle fauna (Coleoptera: Carabidae) along successional gradients in post-industrial areas in Central Poland
}

\author{
AXEL SCHWERK \\ Laboratory of Evaluation and Assessment of Natural Resources, Warsaw University of Life Sciences - SGGW, \\ Nowoursynowska Street 166, 00-240 Warsaw, Poland; e-mail: aschwerk@yahoo.de
}

Key words. Carabidae, post-industrial area, succession, Central Poland, Mean Individual Biomass, landscape

\begin{abstract}
An inventory of the carabid fauna was carried out in two post-industrial areas in central Poland. The two areas studied were a heap of ash generated by a power station and a colliery spoil heap. In each area sites of different ages were investigated using pitfall traps over an eight year period from 2004 to 2011. At the end of this period each of the youngest sites was as old, or even older, than the next oldest site studied in each area. A pine forest growing on natural soil close to the ash heap was included as a reference study site. Changes were described in terms of the numbers of species and individuals, total biomass, Mean Individual Biomass of Carabidae (MIB) and the most frequently collected species. Indirect and direct gradient analyses were carried out in order to determine the environmental basis of the major pattern in variation and analyse the relationships with current environmental parameters. During the eight years of this study 5032 individuals of 84 species were collected. Numbers of individuals decreased significantly with the age of the sites on the ash heap and the MIB values increased significantly on both heaps. Changes in the most frequently collected species were more pronounced on the spoil heap, the study sites on which covered a time span of 26 years, than on the ash heap, for which the period was only 11 years. Characteristic species differed on the spoil and ash heaps and numbers of species were lower on the spoil heap. Despite differences in speed of succession at the sites studied, there was a tendency for the MIB to increase after about 9 to 16 years. Indirect and direct gradients analyses confirmed that the stage of succession (age of the study sites) was an important factor determining the carabid assemblages at the sites studied. The results of this study are important for the restoration and management of post-industrial areas.
\end{abstract}

\section{INTRODUCTION}

Currently there are large parts of the earth' surface that have been considerably altered by human activity, particularly in urban and industrial landscapes, and show a significant loss in terms of green space. In these regions there is a special need for green areas, which are important not only for recreation and improving living conditions for humans, but also as refuges for native species (Mabelis, 2005). With respect to the latter former industrial areas are identified as important (e.g. Rebele \& Dettmar, 1996). Therefore, even if post-industrial environments are heavily altered by humans, such habitats should be considered when developing plans for protecting species (Lundholm \& Richardson, 2010).

The conservation potential of post-industrial areas has been known for decades (e.g. Johnson et al., 1978; Gemmell \& Connell, 1984). However, in order to utilize this potential it is important to understand the ecological factors and processes affecting these areas. The process that mainly determines the species assemblages on post-industrial areas is succession, which has been extensively studied (e.g. Dunger, 1968; Neumann, 1971; Parmenter \& MacMahon, 1987; Majer, 1989; Pflug, 1998; Schwerk et al., 2004; Novák \& Konvička, 2006). Despite the very high heterogeneity of these areas the results of the above studies indicate that succession is often delayed and these areas host many rare and endangered species.
Most studies on succession tackle this task by analyzing study sites of the same type but of varying ages. The sites are chosen in such a manner that any environmental differences between them are minimized as much as possible. However, differences in initial conditions may weaken the comparability of such sites. This problem can be avoided by studying a true time series at a single site. However, long-term monitoring of the changes occurring at a single site is comparatively rare. In the present paper both approaches were used simultaneously. Two different post-industrial areas - a heap of ash at a power station and a colliery spoil heap - were studied. In each area sites of different ages were investigated over a period of eight years. Consequently, at the end of this period each of the youngest sites was as old, or even older, than the next oldest site studied in each area. Thus, succession can be traced at each site over a period of eight years and over the total time span covered by the sites for each heap (ash heap or colliery spoil heap respectively). Additionally, a pine forest growing on natural soil was included as a reference site.

The basic aim of this paper is to trace succession at two post-industrial areas using carabid beetles as indicators (Koivula, 2011). A preliminary analysis of the data collected in the first three years 2004-2006 (Schwerk \& Szyszko, 2008) revealed that succession was delayed at both heaps. Advanced stages of succession at the sites differed from that recorded at the reference site on natural soil. Many species were restricted to particular habitats and stages of succession. Several regionally rare species were detected, 
especially in young stages of succession, on both heaps. The present paper is based on data enlarged by a further five years, which enabled me to compare in detail changes in succession that occurred at each heap and site, including that of individual species, and determine the effect of time and site characteristics on the changes. In order to achieve this I studied changes in basic parameters of the carabid fauna (numbers of species, numbers of individuals, total biomass) and in the numbers of the ten most frequently collected species at each of the heaps studied. The stage of succession was determined by using the Mean Individual Biomass of Carabidae (MIB) as a synthetic indicator (Szyszko, 1990; Szyszko et al., 2000). This method assumes an ongoing process of ecological succession during which the MIB of carabid conenoses increases, because small species of open areas are replaced first by eurytopic and later by stenotopic forest species. The latter species are the largest and heaviest (Szyszko et al., 2000). MIB has been frequently used for assessing the state of succession in a habitat (e.g. Szyszko et al., 1996, 2000; Serrano \& Gallego, 2004; Schwerk et al., 2006; Cárdenas \& Hidalgo, 2007; Šerić Jelaska et al., 2011). Additionally, indirect and direct gradient analysis was used to obtain information about the environmental determinants of the major pattern in variation and analyse the relationships with current environmental factors (ter Braak \& Prentice, 1988). The results were used to test the following hypotheses: (1) Succession at the study sites should in particular be expressed in terms of a change from species typical of for young sites (open habitat species) to those typical of advanced stages of succession (forest species) as well as an increase in MIB values; (2) Species characteristic of specific stages of succession differ at the two areas; (3) Initial environmental conditions at the sites affect the speed of succession; (4) Stage of succession (age of the study sites) is a major factor in the ordination of species and sites compared to type of heap and year of sampling.

\section{MATERIAL AND METHODS}

\section{Study areas and collecting methods}

The study areas are located in central Poland close to the city of Bełchatów. The industrial activity at Bełchatów consists of mining for brown coal and using it to produce electricity, which resulted in two heaps of waste material, one of stony material produced during the mining process and a second of ashes produced by the power station. Eight sites were sampled on different old parts of the ash heap ( 3 sites) and in pine stands of different ages on the spoil heap (4 sites). A pine forest on natural soil was used as reference site (Table 1).

Carabids were collected using pitfall traps (Barber, 1931). Three pitfall traps were set about $5 \mathrm{~m}$ apart at each site. The location of the traps was the same in each year of the study. Traps were glass jars topped with a funnel (upper diameter of about 10 $\mathrm{cm}$ ) set flush with the soil surface. A roof was suspended a few $\mathrm{cm}$ above the funnel and ethylene glycol was used as a killing agent and preservative. Carabids were sampled in 2004 to 2011 from $\mathrm{mid} /$ late-April (beginning of May in 2010) to mid/late-October.

Determination and nomenclature of the individuals collected was carried out according to Freude et al. (2004).

\section{Data analyses}

For each site the catches of the three traps were pooled. Since in some samples the number of individuals was very low, the data for two consecutive years were also pooled, resulting in four samples for each site.

For each of these samples the numbers of species and individuals, total biomass and MIB were calculated. MIB is calculated by dividing the biomass of all the carabids in a sample by the number of specimens caught. Biomass values for the species recorded are those cited by Szyszko (1990) or obtained using the formula of Szyszko (1983), which describes the relationship between the body length of a single carabid individual $(x)$ and its biomass $(y)$ :

$$
\ln y=-8.92804283+2.55549621 \times \ln x
$$

For both the ash and spoil heaps the correlation between the changes in numbers of species, numbers of individuals, total biomass, MIB values and numbers of the ten most frequently collected species and ages of the respective sites was tested using Spearman rank correlation (Sachs, 1984).

In order to study the potential influence of the ash and spoil heaps on succession, Analyses of Covariance (ANCOVA) were carried out with age of the sites as a covariate and numbers of species, numbers of individuals, total biomass, MIB values and numbers of the two most frequently collected species (Calathus erratus, Pterostichus niger) as dependent variables. The initial models included interactions with the covariate, but all non-significant interactions were removed from the final model.

Spearman rank correlations and ANCOVA were carried out using IBM SPSS Statistics v. 21.

The CANOCO for Windows version 4.53 (ter Braak, 1987; ter Braak \& Šmilauer, 2002) was used to perform gradient analyses. Indirect gradient analysis was used to obtain information about the environmental basis determining the major pattern in variation (ter Braak \& Prentice, 1988). This was done for the sites on the ash and spoil heaps separately. Results for both heaps and the control site on natural soil were included in a direct gradient analysis, in order to analyse the relationships with environmental parameters (ter Braak \& Prentice, 1988). Age of the sites, year of

TABLE 1. Description of the sites studied. Sites 1B-3B, were on the ash heap; 4B, in the forest stand and 5B-8B, on the spoil heap.

\begin{tabular}{ccc}
\hline Sites studied & Type & Description \\
\hline 1B & Ash heap & Plantation, about 8 years old in 2004, dominated by Robinia pseudoacacia, Hippophäe rhamnoides \\
and Caragana arborescens \\
2B & Ash heap & Plantation, about 10 years old in 2004, dominated by Betula sp. and Pinus sylvestris \\
3B & Ash heap & Plantation, about 12 years old in 2004, dominated by Robinia pseudoacacia and Hippophäe rhamnoides \\
4B & Forest stand & Pine stand on natural soil, about 65 years old in 2004 \\
5B & Spoil heap & Pine plantation, 3 years old in 2004 \\
6B & Spoil heap & Pine plantation, 10 years old in 2004 \\
7B & Spoil heap & Pine plantation, 14 years old in 2004 \\
8B & Spoil heap & Pine plantation, 21 years old in 2004 \\
\hline
\end{tabular}


sampling and type of heap were included as environmental variables, with the latter two defined as nominal variables.

DCA and DCCA were first used to select the appropriate statistical model based on the longest gradient (Lepš \& Šmilauer, 2003) and then Correspondence Analyses (CA) and Canonical Correspondence Analysis (CCA) were carried out. Dominance values (percentage share of the respective species in a sample) for the carabid species at the different sites were used. The analyses were performed using inter-sample distance scaling and Hill's scaling and un-weighted data for each of the species. Because dominance values were used, the data were not transformed. The significance of the individual environmental variables included in the CCA was tested using Monte Carlo permutation tests (unrestricted, 1999 permutations) first for each variable separately and then using automatic forward selection of variables (reduced model) (ter Braak \& Šmilauer, 2002).

\section{RESULTS}

\section{General results}

Altogether, 5032 individuals of 84 species were collected (Table 2). The four most frequently collected species Calathus erratus (1270 individuals), Pterostichus niger (1087 individuals), Carabus arvensis (743 individuals) and Harpalus flavescens (495 individuals) accounted for more than $70 \%$ of all the carabids collected. Calathus erratus and Pterostichus niger were collected regularly on both heaps, whereas Harpalus flavescens was collected almost exclusively on the ash heap and Carabus arvensis almost exclusively in the pine forest on the reference site.

At each site fluctuations in numbers of individuals and more moderate fluctuations in species numbers were recorded. Consequently, there were also noticeable fluctuations in total biomass.

\section{Changes in basic parameters and numbers of the most frequently collected species}

Numbers of species and total biomass did not change significantly with increasing age of the sites sampled on both heaps. The number of individuals collected on the spoil heap did not change significantly with age but decreased significantly with increase in age on the ash heap $(\mathrm{r}=-0.706, \mathrm{p}<0.05)$.

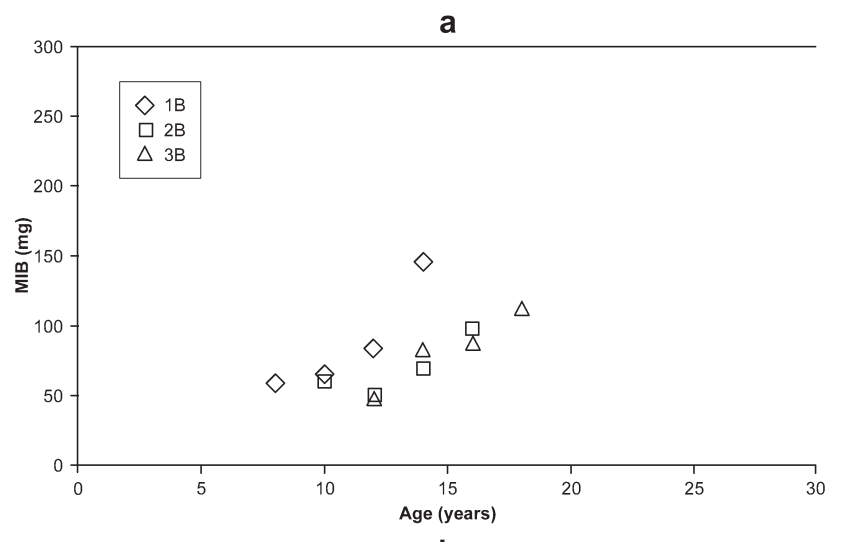

b

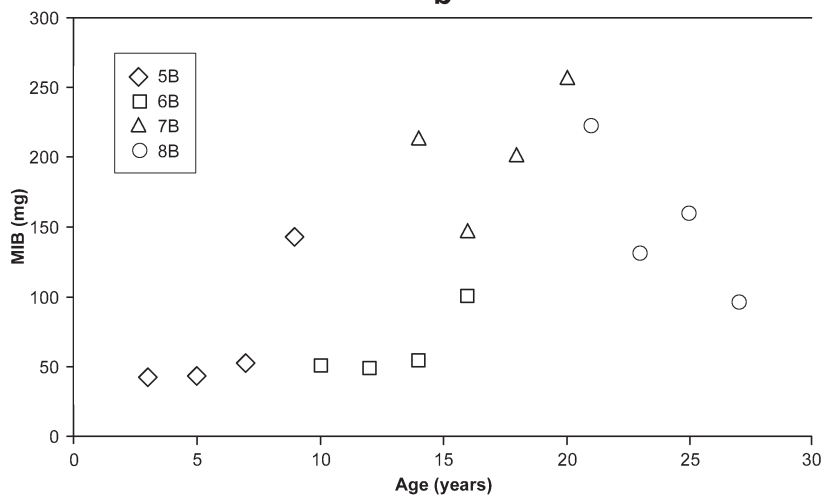

Fig. 1. Relationship between MIB values ( $\mathrm{mg}$ ) and age of the sites studied: (a) sites on the ash heap $(r=0.747, p<0.01)$, (b) sites on the spoil heap $(r=0.649, p<0.01)$. Age refers to the respective first year the pooled samples were collected.

On the ash heap MIB values increased significantly with age (Fig. 1a, $\mathrm{r}=0.747, \mathrm{p}<0.01$ ). This trend was recorded at all three sites studied. Only two MIB values surpassed $100 \mathrm{mg}$, the values recorded in 2010/11 for 3B (18/19 years old) and $1 \mathrm{~B}$ (14/15 years old). The latter had the highest MIB value recorded, $146.5 \mathrm{mg}$. MIB values increased faster at study site $1 \mathrm{~B}$ compared to $2 \mathrm{~B}$ and $3 \mathrm{~B}$, which showed little differences. A significant increase in MIB with age was recorded also on the spoil heap (Fig. 1b, $r=0.649$, $\mathrm{p}<0.01$ ). The young study sites, 5B and $6 \mathrm{~B}$, showed an

TABLE 2. Numbers of species, numbers of individuals, total biomass (mg) and MIB values (mg) recorded for the sites studied in the different years of this study.

\begin{tabular}{cccccccccc}
\hline & & $1 \mathrm{~B}$ & $2 \mathrm{~B}$ & $3 \mathrm{~B}$ & $4 \mathrm{~B}$ & $5 \mathrm{~B}$ & $6 \mathrm{~B}$ & $7 \mathrm{~B}$ & $8 \mathrm{~B}$ \\
\hline \multirow{5}{*}{$2004 / 05$} & Spec & 22 & 22 & 24 & 14 & 11 & 8 & 11 & 17 \\
& Ind & 621 & 281 & 174 & 307 & 165 & 50 & 98 & 117 \\
& Bio & 36770 & 17095 & 8336 & 59405 & 6967 & 2531 & 21033 & 26072 \\
& MIB & 59.21 & 60.84 & 47.91 & 193.5 & 42.22 & 50.62 & 214.6 & 222.8 \\
\hline \multirow{5}{*}{$2006 / 07$} & Spec & 13 & 19 & 14 & 11 & 24 & 8 & 10 & 13 \\
& Ind & 170 & 99 & 63 & 139 & 245 & 59 & 29 & 118 \\
& Bio & 11185 & 5027 & 5217 & 27911 & 10581 & 2878 & 4282 & 15557 \\
& MIB & 65.79 & 50.78 & 82.81 & 200.8 & 43.19 & 48.78 & 147.7 & 131.8 \\
\hline \multirow{5}{*}{$2008 / 09$} & Spec & 14 & 19 & 15 & 13 & 16 & 7 & 14 & 10 \\
& Ind & 59 & 59 & 60 & 377 & 348 & 37 & 83 & 88 \\
& Bio & 4956 & 4102 & 5227 & 78430 & 18192 & 2037 & 16824 & 14112 \\
& MIB & 84 & 69.53 & 87.12 & 208 & 52.28 & 55.05 & 202.7 & 160.4 \\
\hline & Spec & 14 & 15 & 13 & 19 & 4 & 7 & 13 & 10 \\
& Ind & 120 & 58 & 66 & 659 & 103 & 42 & 97 & 41 \\
& Bio & 17579 & 5703 & 7355 & 138000 & 14697 & 4221 & 24926 & 3963 \\
& MIB & 146.5 & 98.33 & 111.4 & 209.4 & 142.7 & 100.5 & 257 & 96.66 \\
\hline
\end{tabular}


TABLE 3. The numbers of the most frequently collected species recorded on sites of different ages on the ash heap. ${ }^{*} \mathrm{p}<0.05$; $* * \mathrm{p}<0.01$ (Spearman rank correlation coefficient).

\begin{tabular}{|c|c|c|c|c|c|c|c|c|c|c|c|}
\hline Study site & Age & 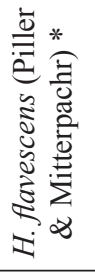 & 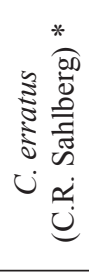 & 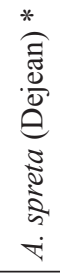 & 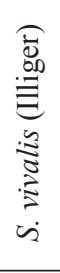 & 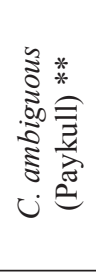 & 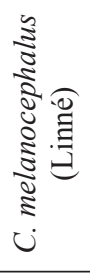 & 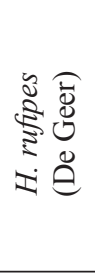 & 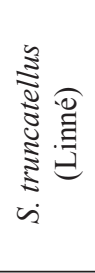 & 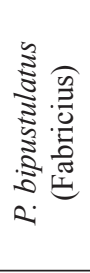 & 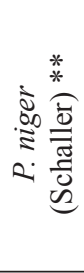 \\
\hline $\begin{array}{c}1 \mathrm{~B} \\
(2004 / 05)\end{array}$ & $8 / 9$ & 298 & 180 & 40 & 26 & 24 & 12 & 12 & 3 & 2 & \\
\hline $\begin{array}{c}1 \mathrm{~B} \\
(2006 / 07)\end{array}$ & $10 / 11$ & 92 & 55 & 1 & 7 & 2 & 1 & 1 & 3 & & 4 \\
\hline $\begin{array}{c}2 \mathrm{~B} \\
(2004 / 05)\end{array}$ & $10 / 11$ & 87 & 107 & 1 & & 28 & 1 & 18 & 1 & & \\
\hline & $12 / 13$ & & 5 & & 19 & & 1 & & 2 & 5 & 14 \\
\hline $\begin{array}{c}2 \mathrm{~B} \\
(2006 / 07)\end{array}$ & $12 / 13$ & 12 & 49 & & & & 12 & 1 & 1 & 1 & 2 \\
\hline $\begin{array}{c}3 \mathrm{~B} \\
(2004 / 05)\end{array}$ & $12 / 13$ & & 59 & & & & 20 & 1 & 29 & 6 & 1 \\
\hline $\begin{array}{c}1 \mathrm{~B} \\
(2010 / 11)\end{array}$ & $14 / 15$ & & 23 & & 12 & & & 1 & 1 & 2 & 70 \\
\hline $\begin{array}{c}2 \mathrm{~B} \\
(2008 / 09)\end{array}$ & $14 / 15$ & 3 & 3 & 1 & & & 3 & 5 & 6 & 5 & 6 \\
\hline $\begin{array}{c}3 \mathrm{~B} \\
(2006 / 07)\end{array}$ & $14 / 15$ & & 2 & & & & 3 & 2 & 20 & 6 & 5 \\
\hline $\begin{array}{c}2 \mathrm{~B} \\
(2010 / 11)\end{array}$ & $16 / 17$ & 1 & 25 & & 1 & & 4 & 3 & 2 & 1 & 10 \\
\hline $\begin{array}{c}3 \mathrm{~B} \\
(2008 / 09)\end{array}$ & $16 / 17$ & & 13 & & & & 1 & 5 & 1 & 11 & 8 \\
\hline $\begin{array}{c}3 \mathrm{~B} \\
(2010 / 11)\end{array}$ & $18 / 19$ & & 22 & & 3 & & 1 & & 1 & 4 & 26 \\
\hline
\end{tabular}

increasing trend in MIB with age, reaching values of about $150 \mathrm{mg}$ (5B) and about $100 \mathrm{mg}$ (6B) based on the data collected in 2010/11. Comparatively high MIB values were recorded regularly at $7 \mathrm{~B}$, ranging from about $150 \mathrm{mg}$ up to more than $250 \mathrm{mg}$. At study site $8 \mathrm{~B}$ a decreasing trend from more than $200 \mathrm{mg}$ to about $100 \mathrm{mg}$ was recorded.

On the ash heap, on which the age of the study sites covers a time span of 11 years (Table 3 ), the ten most frequently collected species made up $85.7 \%$ of all individuals caught. The youngest of the study sites were dominated by Harpalus flavescens, Calathus erratus and Amara spreta. The number of these species and those of Calathus ambiguus decreased significantly with increase in the age of the study sites. Species that showed a non-significant preference for young sites were Synuchus vivalis, Calathus melanocephalus and Harpalus rufipes, whereas Syntomus truncatellus and Panagaeus bipustulatus showed no preference. The numbers of Pterostichus niger increased significantly with increase in age of the sites.

On the spoil heap the ten most frequently collected species made up $81.9 \%$ of all the individuals caught. Since the age of the study sites covered a time span of 26 years, the changes in carabid species were much more pronounced (Table 4). Calathus erratus, Amara aenea, Harpalus anxius and Harpalus rubripes dominated the young sites (statistically significant for Calathus erratus). With the exception of Calathus erratus, which was collected in higher numbers on sites of up to 16 years old, these species were almost completely absent from sites seven years old and older. Pterostichus niger was collected in higher numbers on older sites (from about 14 years), but was also frequently present on sites of 7 years old and older. Leistus ferrugineus was collected on 14 to 21 year old sites. Carabus violaceus was frequently collected at sites 14 years old and older, whereas the highest numbers of Carabus auronitens, Amara communis and Harpalus xanthopus winkleri were collected at sites aged 18 years or older. The latter three species significantly increased in numbers with increase in age of the sites.

The ANCOVA (Table 5) revealed a significant difference in numbers of species, numbers of individuals and total biomass of carabids caught on the spoil and ash heaps. Numbers of individuals, MIB values and numbers of $\mathrm{Ca}$ lathus erratus changed significantly with age of the sites. Yet, with respect to numbers of individuals and total biomass there was a significant interaction between type of heap and age of the sites sampled.

\section{Gradient analyses}

The correspondence analysis $(\mathrm{CA})$ revealed for the ash heap (Fig. 2) that the first ordination axis explained 28.4\% and the second ordination axis $22.0 \%$ of the variation in the dataset. The oldest site $3 \mathrm{~B}$ is located on the left side of the diagram, whereas sites $1 \mathrm{~B}$ and $2 \mathrm{~B}$ are located on the right side and show a shift towards the left side with increase in age of the site. This shift was more pronounced for $1 \mathrm{~B}$, which even surpassed site $3 \mathrm{~B}$. The first ordination 
TABLE 4. The numbers of the most frequently collected species recorded on sites of different ages on the spoil heap. ${ }^{*} \mathrm{p}<0.05$; $* * \mathrm{p}<0.01 ; * * * \mathrm{p}<0.001$ (Spearman rank correlation coefficient).

\begin{tabular}{|c|c|c|c|c|c|c|c|c|c|c|c|c|}
\hline Study site & Age & 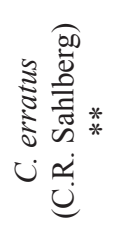 & 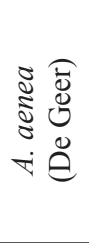 & 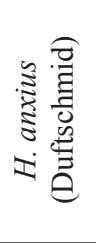 & 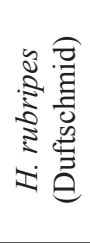 & 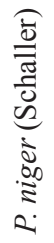 & 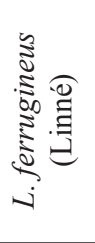 & 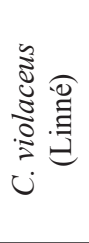 & 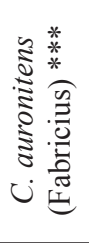 & 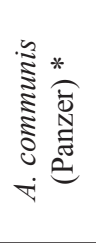 & 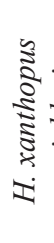 & 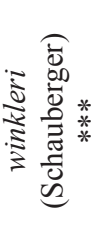 \\
\hline $\begin{array}{c}5 \mathrm{~B} \\
(2004 / 05)\end{array}$ & $3 / 4$ & 103 & 15 & 15 & 4 & & & & & & & \\
\hline $\begin{array}{c}5 \mathrm{~B} \\
(2006 / 07)\end{array}$ & $5 / 6$ & 154 & 14 & 18 & 17 & 1 & & & & & & \\
\hline $\begin{array}{c}5 \mathrm{~B} \\
(2008 / 09)\end{array}$ & $7 / 8$ & 285 & 5 & 1 & 8 & 11 & & & & & & \\
\hline $\begin{array}{c}5 \mathrm{~B} \\
(2010 / 11)\end{array}$ & $9 / 10$ & 39 & & & & 58 & & & & & & \\
\hline & $10 / 11$ & 39 & & & & 1 & & & & & & \\
\hline & $12 / 13$ & 49 & & & 2 & & & & & & & \\
\hline $\begin{array}{c}6 \mathrm{~B} \\
(2008 / 09)\end{array}$ & $14 / 15$ & 29 & & & & 2 & 1 & & & & & \\
\hline $\begin{array}{c}7 \mathrm{~B} \\
(2004 / 05)\end{array}$ & $14 / 15$ & & & & 4 & 56 & 9 & 1 & & & & \\
\hline $\begin{array}{c}6 \mathrm{~B} \\
(2010 / 11)\end{array}$ & $16 / 17$ & 19 & & & & 13 & & & & & & \\
\hline $\begin{array}{c}7 \mathrm{~B} \\
(2006 / 07)\end{array}$ & $16 / 17$ & & & & & 11 & 5 & 1 & 2 & 1 & & \\
\hline $\begin{array}{c}7 \mathrm{~B} \\
(2008 / 09)\end{array}$ & $18 / 19$ & & & & 1 & 43 & 13 & 4 & 10 & & & \\
\hline $\begin{array}{c}7 \mathrm{~B} \\
(2010 / 11)\end{array}$ & $20 / 21$ & & & & & 67 & 2 & 9 & & & & \\
\hline $\begin{array}{c}8 \mathrm{~B} \\
(2004 / 05)\end{array}$ & $21 / 22$ & & & & & 42 & & 7 & 18 & 7 & & 4 \\
\hline $\begin{array}{c}8 \mathrm{~B} \\
(2006 / 07)\end{array}$ & $23 / 24$ & & & & & 13 & & & 25 & 24 & & 11 \\
\hline $\begin{array}{c}8 \mathrm{~B} \\
(2008 / 09)\end{array}$ & $25 / 26$ & & & & & 29 & & 2 & 14 & 6 & & 24 \\
\hline $\begin{array}{c}8 \mathrm{~B} \\
(2010 / 11)\end{array}$ & $27 / 28$ & & & & & 9 & & 1 & 1 & & & 20 \\
\hline
\end{tabular}

TABLE 5. Results of the ANCOVAs of numbers of species, numbers of individuals, total biomass, MIB values, numbers of Calathus erratus and numbers of Pterostichus niger. Type - areas studied; Age - age of sites studied.

\begin{tabular}{|c|c|c|c|c|c|c|}
\hline Dep. var. & Factor & Type III SS & $\mathrm{df}$ & MS & $\mathrm{F}$ & $p$ \\
\hline \multirow{3}{*}{$\begin{array}{l}\text { Numbers } \\
\text { of species }\end{array}$} & Type & 184.274 & 1 & 184.274 & 9.190 & 0.006 \\
\hline & Age & 18.634 & 1 & 18.634 & 0.929 & 0.344 \\
\hline & Error & 501.304 & 25 & 20.052 & & \\
\hline \multirow{4}{*}{$\begin{array}{c}\text { Numbers } \\
\text { of individuals }\end{array}$} & Type & 110048.636 & 1 & 110048.636 & 12.678 & 0.002 \\
\hline & Age & 189193.482 & 1 & 189193.482 & 21.795 & 0.000 \\
\hline & Type $\times$ Age & 106271.679 & 1 & 106271.679 & 12.243 & 0.002 \\
\hline & Error & 208332.841 & 24 & 8680.535 & & \\
\hline \multirow{4}{*}{ Total biomass } & Type & 381824991.410 & 1 & 381824991.410 & 5.894 & 0.023 \\
\hline & Age & 273881300.549 & 1 & 273881300.549 & 4.228 & 0.051 \\
\hline & Type $\times$ Age & 439985526.784 & 1 & 439985526.784 & 6.792 & 0.015 \\
\hline & Error & 1554793797.942 & 24 & 64783074.914 & & \\
\hline \multirow{3}{*}{ MIB values } & Type & 6403.019 & 1 & 6403.019 & 2.693 & 0.113 \\
\hline & Age & 28969.166 & 1 & 28969.166 & 12.185 & 0.002 \\
\hline & Error & 59436.550 & 25 & 2377.462 & & \\
\hline \multirow{3}{*}{$\begin{array}{l}\text { Numbers } \\
\text { of } C . \text { erratus }\end{array}$} & Type & 1644.572 & 1 & 1644.572 & 0.638 & 0.432 \\
\hline & Age & 55702.255 & 1 & 55702.255 & 21.626 & 0.000 \\
\hline & Error & 64392.433 & 25 & 2575.697 & & \\
\hline \multirow{3}{*}{$\begin{array}{l}\text { Numbers } \\
\text { of } P \text {. niger }\end{array}$} & Type & 405.077 & 1 & 405.077 & 0.894 & 0.353 \\
\hline & Age & 1102.067 & 1 & 1102.067 & 2.432 & 0.131 \\
\hline & Error & 11328.600 & 25 & 453.144 & & \\
\hline
\end{tabular}




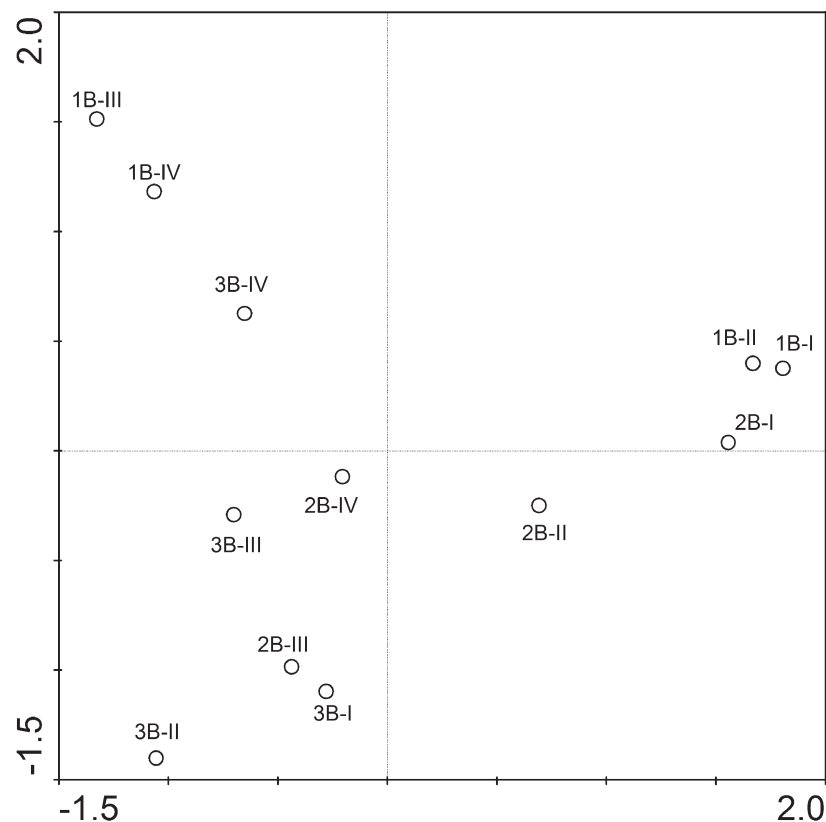

Fig. 2. Ordination plot based on correspondence analysis (CA) of the results for the sites (open circles) on the ash heap. Numbers of sites studied as listed in Table 1 with the year of study (I $=2004 / 05, \mathrm{II}=2006 / 07, \mathrm{III}=2008 / 09, \mathrm{IV}=2010 / 11$ ) attached.

axis of the CA of the sites on the spoil heap (Fig. 3) explained $35.2 \%$ and the second ordination axis $17.1 \%$ of the variation in the dataset. As on the ash heap, the sites were separated according to their age when the carabids were caught along the first ordination axis, with sites that were young at the beginning of the study located on the right side and those that were older on the left side. The samples collected at 5B and 6B in 2010/11 are shifted towards the left side on the diagram. The older sites, $7 \mathrm{~B}$ and $8 \mathrm{~B}$, are separated along the second ordination axis.

The first canonical axis of the CCA (Fig. 4) explained $15.7 \%$ of the variation in species data and $37.2 \%$ of that in the species-environment relationship. The second canonical axis explained $12.5 \%$ and $30.4 \%$, respectively. The sites were separated along the first ordination axis with respect to age, with young sites $(1 \mathrm{~B}, 2 \mathrm{~B}, 3 \mathrm{~B}, 5 \mathrm{~B}, 6 \mathrm{~B})$ located on the left side of the diagram and old sites $(4 \mathrm{~B}$, $7 \mathrm{~B}, 8 \mathrm{~B}$ ) on the right side. Sites $7 \mathrm{~B}$ and $8 \mathrm{~B}$ were separated

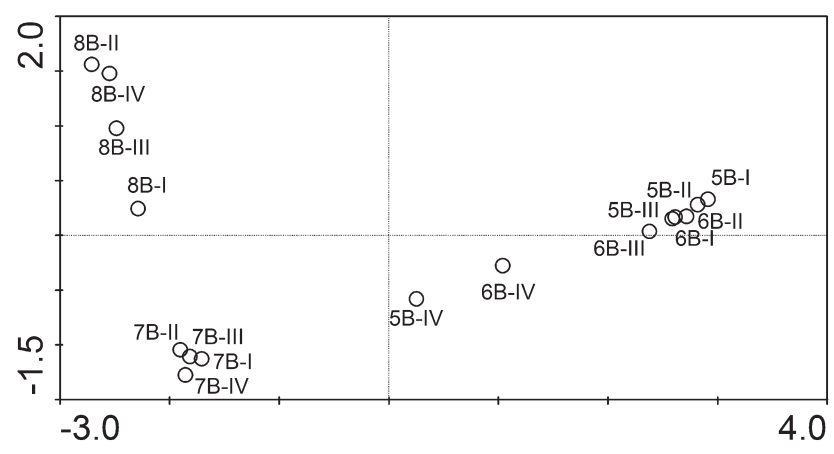

Fig. 3. Ordination plot based on correspondence analysis (CA) of the results for the sites (open circles) on the spoil heap. Numbers of the sites studied as listed in Table 1 with the year of study $(I=2004 / 05, I I=2006 / 07, I I I=2008 / 09, I V=2010 / 11)$ attached.

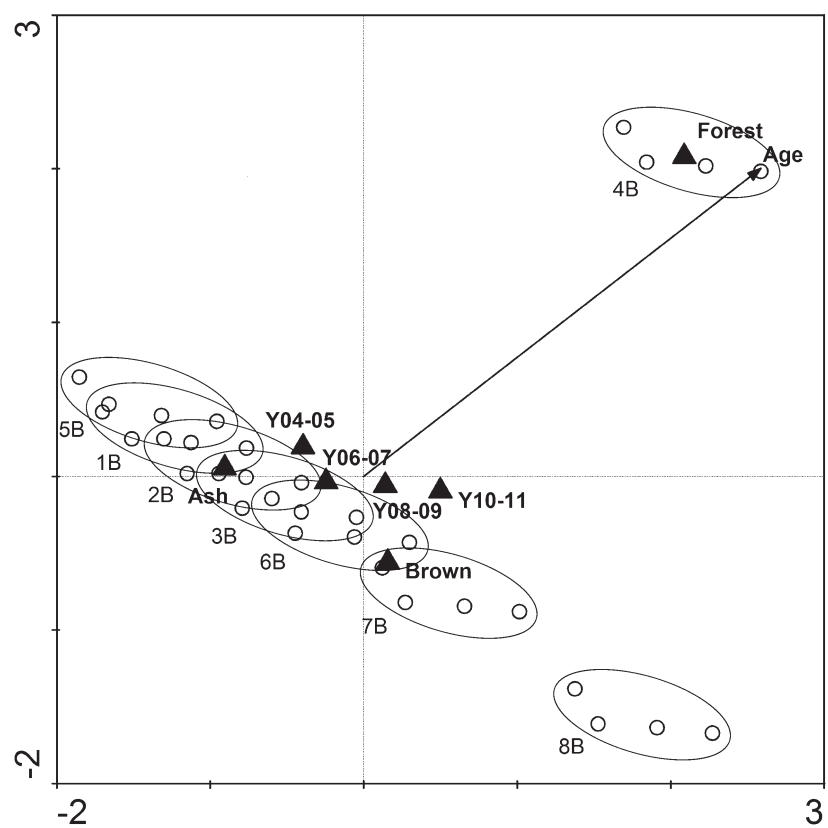

Fig. 4. Ordination plot based on canonical correspondence analysis (CCA) of the results for sites (open circles) and environmental variables (triangles and arrow) for all the areas studied. Ovals indicate the range in the values of the samples from particular sites. Numbers of the sites studied as listed in Table 1. Age - age of the sites; Forest, ash and spoil heaps - areas studied; Y10-11, Y08-09, Y04-05 and Y06-07 - respective years of the study.

from 4B along the second ordination axis. Age of the sites and type of heap had a stronger influence on the ordination results, whereas the close location of the centroids of the dummy variables representing the years of study indicated only minor differences between the years. Thus, the age of the sites and type of heap account for most of the variance when considered singly (lambda-1 values, Table 6). These environmental variables were statistically significant when tested separately and contributed also statistically signifi-

TABLE 6. Results of Monte Carlo permutation tests of the environmental variables tested separately and using automatic forward selection of variables (reduced model). During forward selection of variables "Brown" and "Y06-07" were not added to the model due to collinearity. Lambda-1 - variance explained by the environmental variables separately; Lambda-A - additional variance explained when included in the model using forward selection; Age - age of the sites; Forest, ash and spoil heaps - areas studied; Y10-11, Y08-09, Y04-05 and Y06-07 - respective years of the study.

\begin{tabular}{cccccccc}
\hline \multirow{2}{*}{ Variable } & \multicolumn{3}{c}{ Tested separately } & \multicolumn{3}{c}{ Forward selection } \\
\cline { 2 - 7 } & Lambda-1 & $\mathrm{F}$ & $p$ & Lambda-A & $\mathrm{F}$ & $p$ \\
\hline Age & 0.58 & 5.06 & 0.001 & 0.58 & 5.06 & 0.001 \\
Forest & 0.54 & 4.70 & 0.001 & 0.51 & 5.06 & 0.001 \\
Ash heap & 0.38 & 3.14 & 0.001 & 0.30 & 3.31 & 0.001 \\
Spoil heap & 0.36 & 2.99 & 0.001 & - & - & - \\
Y10-11 & 0.14 & 1.10 & 0.331 & 0.14 & 1.46 & 0.096 \\
Y08-09 & 0.10 & 0.61 & 0.908 & 0.10 & 1.09 & 0.341 \\
Y04-05 & 0.08 & 0.75 & 0.770 & 0.04 & 0.46 & 0.985 \\
Y06-07 & 0.08 & 0.58 & 0.933 & - & - & - \\
\hline
\end{tabular}


cantly after inclusion to the model at forward selection of environmental variables as revealed by Monte Carlo permutation tests (Table 6).

\section{DISCUSSION AND CONCLUSIONS}

As expected, on both heaps succession occurred (cf. hypothesis 1) in terms of changes in numbers of the dominant species and an increase in MIB values. Analogous changes in species occurring on reclaimed brown coal mining sites are regularly reported (e.g. Mader, 1985; Neumann, 1991; Vogel \& Dunger, 1991; Kielhorn \& Keplin, 1999). In particular, Calathus erratus is characteristically present in the pioneer stages whereas Pterostichus niger occurs in a wider range of stages of succession. Characteristic species of the two heaps differ (cf. hypothesis 2), possibly because their environmental conditions differ. For example, Kielhorn \& Keplin (1999) report Harpalus flavescens and Calathus ambiguous as dominant species on a newly reclaimed brown coal mining site, which was meliorated by the addition of ash. In the present study, both these species were among the most frequently collected carabids on the ash heap. The effect of the nature of the heap on the species is corroborated by the difference in numbers of species recorded on the two heaps.

Succession in terms of changes in MIB values measured over several years on the sites studied was delayed compared to that recorded for many areas on less disturbed soil, such as pine stands on former arable land (Schwerk \& Szyszko, 2011) or beech stands on natural soil (Schreiner, 2011). This delay is characteristic of many post-industrial sites (e.g. Majer, 1989; Dmowska, 2005). However, succession at some sites was faster than at others (cf. hypothesis 3). These differences might be due to differences in the initial treatment, i.e. different initial conditions. Thus, studies of succession on sites of different ages have to be analyzed carefully. The time needed for the MIB value to surpass $100 \mathrm{mg}$ might be somewhat longer on the ash than the spoil heap; however, the ANCOVA did not reveal a statistically significant difference in the MIB values for these two heaps. The MIB values of the older sites are low when compared to those of mature stands (e.g. Szyszko, 1990; Skłodowski, 2006, 2009; Schreiner, 2011) indicating an incomplete regeneration of the sites. Analogously, a study by Majer (1989) of surface-mine spoils in Illinois shows that the numbers of species of thrips (Thrysanoptera) were still less than that recorded in control areas after 32 years. Delayed succession and incomplete regeneration even after a long period seem to be characteristic of degraded areas (Schwerk, 2008; Schwerk \& Szyszko, 2011). The decrease in MIB values recorded for site $8 \mathrm{~B}$ may be due to fluctuations in biotic and abiotic factors influencing the carabid assemblage. Magura et al. (2006) report a noticeable influence of several factors in Norway spruce plantations. The particularly low MIB value recorded for this site in $2010 / 11$ is due to an exceptionally high number of individuals of Harpalus xanthopus winkleri collected in 2011.

The distribution of the sites along the first ordination axis for both heaps indicates that the stage of succession is an important factor determining the carabid assemblages (cf. hypothesis 4). Age of the sites was also indicated to be of major importance by the CCA. Accordingly, in the ANCOVA MIB values used as an indicator of succession changed significantly with age of the sites. However, the separation of the old post-industrial sites from the reference site, which was in natural forest, along the second ordination axis in Fig. 4 indicates that the succession on disturbed soils differs from that on undisturbed soil. A study of the pattern in the early stages of succession in terms of re-colonization by arthropods of reclaimed strip mines in Southwestern Wyoming, reports that the ground-dwelling beetle fauna differed in terms of its trophic structure from that of the fauna at undisturbed sites (Parmenter \& MacMahon, 1987).

It is assumed that the results of this study will increase our understanding of succession at post-industrial sites and the potential for using these areas for conservation purposes at a landscape level. As shown by this study, the species assemblages recorded differed at different stages of succession. Thus, this process has to be taken into account when managing such areas to bring about a fast and natural type of succession. For this it is necessary to facilitate succession from the beginning by undertaking reclamation measures, which take into consideration the relationship between the plants to be used and the current state of the environmental factors (Jochimsen, 2001).

The management of post-industrial areas should also consider the conservation of species diversity. The overall number of species recorded in this study is comparatively high and several species are rare in this region (Schwerk \& Szyszko, 2008). Several studies also show that such sites host valuable species belonging to other taxonomic groups (e.g. Abs et al., 1999; Tropek et al., 2012, 2013a, b). Venn (2013) stresses the importance of establishing artificial habitats as a means of increasing urban biological diversity. Thus, post-industrial areas could be used for conservation purposes. In this respect a fast succession may not be desirable because the rare carabids recorded in this study (Schwerk \& Szyszko, 2008) indicate that some sites should be kept at a young stage of succession. That some parts of post-industrial areas should be un-reclaimed in order to support biological diversity has been previously mentioned in the literature (e.g. Mader, 1985; Rebele \& Dettmar, 1996; Kielhorn \& Keplin, 1999; Barndt et al., 2006; Hendrychová et al., 2008). Kabrna (2011) and Tropek et al. (2012) favour spontaneous succession over technical reclamation and re-cultivation practices. However, since succession results in a stepwise loss of young stages and habitat homogenization, dynamic management (Rebele \& Dettmar, 1996) is required. This should consider the biotopes in the surrounding landscape (e.g. Novák \& Konvička, 2006), dispersal abilities of species and differences in succession on different sites, as reported in the present study. Carabids may serve as useful indicators when managing post-industrial areas.

ACKNOWLEDGEMENTS. The author thanks K. Hannig for confirming the identification of beetles difficult to identify and 
two anonymous reviewers, who provided very valuable comments on an earlier version of the paper. This paper is communication No. 443 of the Laboratory of Evaluation and Assessment of Natural Resources, Warsaw University of Life Sciences - SGGW.

\section{REFERENCES}

Abs M., Schwerk A. \& Zeiss A. 1999: Bergehalden im Ruhrgebiet eine Oase für Tiere? - BIUZ 6: 346-352.

BARBER H.S. 1931: Traps for cave inhabiting insects. - J. Elisha Mitchell Sci. Soc. 46: 259-266.

Barndt D., Landeck I. \& Wiedemann D. 2006: Sukzession der Laufkäferfauna (Col.: Carabidae) in der Bergbaufolgelandschaft Grünhaus (Brandenburg: Niederlausitz). — Märkische Entomol. Nachr. 8: 81-112.

Cárdenas A.M. \& Hidalgo J.M. 2007: Application of the mean individual biomass (MIB) of ground beetles (Coleoptera, Carabidae) to assess the recovery process of the Guadiamar Green Corridor (southern Iberian Peninsula). - Biodiv. Conserv. 16: 4131-4146.

DMOWsKa E. 2005: Nematodes colonizing powerplant ash dumps. II. Nematode communities in ash dumps covered with turf effect of reclamation period and soil type. - Pol. J. Ecol. 53: $37-51$.

Dunger W. 1968: Die Entwicklung der Bodenfauna auf rekultivierten Kippen und Halden des Braunkohlentagebaus. Ein Beitrag zur pedozoologischen Standortdiagnose. - Abh. Ber. Naturk. Mus. Görlitz 43: 1-256.

Freude H., Harde K.-W., Lohse G.A. \& Klausnitzer B. 2004: Die Käfer Mitteleuropas. Bd. 2, Adephaga 1, Carabidae (Laufkäfer). 2. (erweiterte) Aufl., Spektrum, Heidelberg/Berlin, 521 pp.

Gemmell R.P. \& ConNell R.K. 1984: Conservation and creation of wildlife habitats on industrial land in Greater Manchester. Landsc. Plann. 11: 175-186.

HendRYCHOVÁ M., Š́́leK M. \& ČERVENKOVÁ A. 2008: Invertebrate communities in man-made and spontaneously developed forests on spoil heaps after coal mining. - J. Landsc. Stud. 1: $169-187$.

JOCHIMSEN M.E. 2001: Vegetation development and species assemblages in a long-term reclamation project on mine spoil. - Ecol. Engin. 17: 187-198.

Johnson M.S., Putwain P.D. \& Holliday R.J. 1978: Wildlife conservation value of derelict metalliferous mine workings in Wales. - Biol. Conserv. 14: 131-148.

KABRNA M. 2011: Studies of land restoration on spoil heaps from brown coal mining in the Czech Republic - a literature review. - J. Landsc. Stud. 4: 59-69.

Kielhorn K.-H. \& KePLin B. 1999: Carabidenzoenosen unterschiedlich alter Kiefernaufforstungen auf rekultivierten Kippböden: Struktur der Fauna, regionale Charakteristika und Aspekte des Artenschutzes. In Hüttl R.F., Klem D. \& Weber E. (eds): Rekultivierung von Bergbaufolgelandschaften. Das Beispiel des Lausitzer Braunkohlereviers. Walter de Gruyter, Berlin, New York, pp. 119-130.

KoIvULA M.J. 2011: Useful model organisms, indicators, or both? Ground beetles (Coleoptera, Carabidae) reflecting environmental conditions. In Kotze D.J., Assmann T., Noordijk J., Turin H. \& Vermeulen R. (eds): Carabid Beetles as Bioindicators: Biogeographical, Ecological and Environmental Studies. —ZooKeys 100: 287-317.

LePŠ J. \& ŠMILAUER P. 2003: Multivariate Analysis of Ecological Data using CANOCO. Cambridge University Press, Cambridge, New York, Melbourne, Madrid, Cape Town, Singapore, São Paulo, 284 pp.
Lundholm J.T. \& RichaRdson P.J. 2010: Habitat analogues for reconciliation ecology in urban and industrial environments. J. Appl. Ecol. 47: 966-975.

Mabelis A.A. 2005: Green infrastructure of a city and its biodiversity: take Warsaw as an example. - Fragm. Faun. 48: 231-247.

MAder H.-J. 1985: Die Sukzession der Laufkäfer- und Spinnengemeinschaften auf Rohböden des Braunkohlenreviers. Schriftenreihe Vegetationsk. 16: 167-194.

Magura T., Tóthmérész B. \& Elek Z. 2006: Changes in carabid beetle assemblages as Norway spruce plantations age. - Commun. Ecol. 7: 1-12.

MAJER J.D. 1989: Long-term colonization of fauna in reclaimed land. In Majer J.D. (ed.): Animals in Primary Succession. The Role of Fauna in Reclaimed Lands. Cambridge University Press, Cambridge, New York, Port Chester, Melbourne, Sydney, pp. 143-174.

Neumann U. 1971: Die Sukzession der Bodenfauna (Carabidae (Coleoptera), Diplopoda und Isopoda) in den forstlich rekultivierten Gebieten des Rheinischen Braunkohlenreviers. - Pedobiologia 11: 193-226.

NovÁk J. \& KonvičKa M. 2006: Proximity of valuable habitats affects succession patterns in abandoned quarries. - Ecol. Engin. 26: 113-122.

Parmenter R.R. \& MacMahon J.A. 1987: Early successional patterns of arthropod recolonization on reclaimed strip mines in southwestern Wyoming: the ground-dwelling beetle fauna (Coleoptera). - Environ. Entomol. 16: 168-175.

Pflug W. (ed.) 1998: Braunkohlentagebau und Rekultivierung. Landschaftsökologie - Folgenutzung - Naturschutz. Springer, Berlin, Heidelberg, New York, 1068 pp.

Rebele F. \& Dettmar J. 1996: Industriebrachen. Ökologie und Management. Ulmer, Stuttgart (Hohenheim), 188 pp.

SACHS L. 1984: Angewandte Statistik: Anwendung statistischer Methoden. 6th ed. Springer, Berlin, Heidelberg, New York, Tokyo, 552 pp.

SCHREINER A. 2011: Large carabids prevail in aging forests: Mean Individual Biomass and Carabus dominance as indicators of succession in North Rhine-Westphalian beech forests (Coleoptera: Carabidae). - Angew. Carabidol. 9: 51-55.

Schwerk A. 2008: Model of the Rate of Succession of Epigeic Carabid Beetles (Coleoptera: Carabidae) on Degraded Areas. Instytut Badawczy Leśnictwa, Sękocin Stary, $71 \mathrm{pp}$.

Schwerk A. \& ABs M. 1995: Bergehalden als Lebensraum für Laufkäfer (Coleoptera, Carabidae). — Verh. Ges. Ökol. 24: 581-583.

Schwerk A. \& Szyszko J. 2008: Patterns of succession and conservation value of post-industrial areas in central Poland based on carabid fauna (Coleoptera: Carabidae). In Penev L., Erwin T. \& Assmann T. (eds): Back to the Roots and Back to the Future. Towards a New Synthesis between Taxonomic, Ecological and Biogeographical Approaches in Carabidology. Pensoft Publishers, Sofia, Moscow, pp. 469-481.

Schwerk A. \& Szyszko J. 2011: Model of succession in degraded areas based on carabid beetles (Coleoptera, Carabidae). In Kotze D.J., Assmann T., Noordijk J., Turin H. \& Vermeulen R. (eds): Carabid Beetles as Bioindicators: Biogeographical, Ecological and Environmental Studies. - ZooKeys 100: 319-332.

Schwerk A., Geiss O., Erfmann M. \& Abs M. 2004: Multivariate analysis of a long-term study on carabid beetles (Coleoptera: Carabidae) on a colliery spoil heap in the Ruhr Valley Area. Baltic J. Coleopterol. 4: 13-22. 
Schwerk A., SAŁek P., Duszczyk M., Abs M. \& Szyszko J. 2006: Variability of Carabidae in time and space in open areas. Entomol. Fenn. 17: 258-268.

Šerić Jelaska L., Dumbović V. \& Kučrnić M. 2011: Carabid beetle diversity and mean individual biomass in beech forests of various ages. In Kotze D.J., Assmann T., Noordijk J., Turin H. \& Vermeulen R. (eds): Carabid Beetles as Bioindicators: Biogeographical, Ecological and Environmental Studies. ZooKeys 100: 393-405.

Serrano J. \& Gallego D. 2004: Evaluación de la regeneración y el estado de salud de las masas forestales de Sierra Espuña (Murcia) mediante el análisis de la biomasa media individual en coleópteros carábidos. - Anal. Biol. 26: 191-211.

SkŁodowsKi J.J.W. 2006: Anthropogenic transformation of ground beetle assemblages (Coleoptera: Carabidae) in Białowieża Forest, Poland: from primeval forests to managed woodlands of various ages. - Entomol. Fenn. 17: 296-314.

SKŁodOWSKI J. 2009: Interpreting the condition of the forest environment with use of the SCP/MIB model of carabid communities (Coleoptera: Carabidae). - Baltic J. Coleopterol. 9: 89-100.

SzYszKo J. 1983: Methods of macrofauna investigations. In Szujecki A., Szyzsko J., Mazur S. \& Perliński S. (eds): The Process of Forest Soil Macrofauna Formation after Afforestation of Farmland. Warsaw Agricultural University Press, Warsaw, pp. $10-16$.

SzyszKo J. 1990: Planning of Prophylaxis in Threatened Pine Forest Biocoenoses Based on an Analysis of the Fauna of Epigeic Carabidae. Warsaw Agricultural University Press, Warsaw, 96 pp.

Szyszko J., Vermeulen H.J.W. \& Den Boer P.J. 1996: Survival and reproduction in relation to habitat quality and food availability for Pterostichus oblongopunctatus F. (Carabidae, Col.). - Acta Jutland. 71: 25-40.

Szyszko J., Vermeulen H.J.W., Klimaszewski K., Abs M. \& Schwerk A. 2000: Mean individual biomass (MIB) of ground beetles (Carabidae) as an indicator of the state of the environ- ment. In Brandmayr P., Lövei G., Zetto Brandmayr T., Casale A. \& Vigna Taglianti A. (eds): Natural History and Applied Ecology of Carabid Beetles. Pensoft Publishers, Sofia, Moscow, pp. 289-294.

TER BRAAK C.J.F. 1987: CANOCO - A FORTRAN Program for Canonical Community Ordination by (partial) (detrended) (canonical) Correspondence Analysis, Principal Components Analysis and Redundancy Analysis (version 2.1). DLO-Agricultural Mathematics Group, Wageningen, $95 \mathrm{pp}$.

TER BRAaK C.J.F. \& Prentice I.C. 1988: A theory of gradient analysis. - Adv. Ecol. Res. 18: 271-317.

TER BRAaK C.J.F. \& ŠMILAUER P. 2002: CANOCO Reference Manual and CanoDraw for Windows User's Guide: Software for Canonical Community Ordination (version 4.5). Microcomputer Power, Ithaca, 499 pp.

Tropek R., Kadlec T., Hejda M., Kocarek P., Skuhrovec J., Malenovsky I., Vodka S., Spitzer L., Banar P. \& Konvicka M. 2012: Technical reclamations are wasting the conservation potential of post-mining sites. A case study of black coal spoil dumps. - Ecol. Engin. 43: 13-18.

Tropek R., Cerna I., Straka J., Cizek O. \& Konvicka M. 2013a: Is coal combustion the last chance for vanishing insects of inland drift sand dunes in Europe? - Biol. Conserv. 162: 60-64.

Tropek R., Hejda M., Kadlec T. \& Spitzer L. 2013b: Local and landscape factors affecting communities of plants and diurnal Lepidoptera in black coal spoil heaps: Implications for restoration management. - Ecol. Engin. 57: 252-260.

Venn S. 2013: Managing Forest and Meadow Habitats for the Enhancement of Urban Biodiversity - Messages from Carabid Beetles and Vascular Plants. PhD Thesis, University of Helsinki, $52 \mathrm{pp}$.

Vogel J. \& Dunger W. 1991: Carabiden und Staphyliniden als Besiedler rekultivierter Tagebau-Halden in Ostdeutschland. Abh. Ber. Naturkundemus. Görlitz 65: 1-31.

Received December 2, 2013; revised and accepted March 7, 2014 Prepublished online September 10, 2014 